\title{
Characterization of Mineral-binding 40-kDa Glycoprotein Extracted from Young Adult Rabbit Alveolar Bone
}

\author{
Masao MAENO ${ }^{1}$, Minoru TAGUCHI ${ }^{1}$, Naoto SUZUKI ${ }^{1}$, Tetsuya \\ OGOSHI $^{2}$, Kiyoshi NAGANUMA ${ }^{1}$, Yoshiyuki TAMURA ${ }^{1}$, \\ Kimito NAKANO ${ }^{1}$, Fumio KOMORI ${ }^{1}$, Kichibee OTSUKA ${ }^{1}$ and \\ Kantaro SUZUKI ${ }^{1}$
}

(Received 6 November 1991 and accepted 3 February 1992)

Key words: rabbit alveolar bone, non-collagenous protein, mineral-binding protein, glycoprotein, osteonectin

\begin{abstract}
A forty-kilodalton (40-kDa) protein was extracted from alveolar bone of young adult rabbit with $0.5 \mathrm{M}$ EDTA after extraction with $4 \mathrm{M} \mathrm{GuHCl}$, and purified by gel-filtration, anion-exchange and hydroxyapatite columns using a high-pressure liquid chromatography system under denaturing conditions.

The purified 40-kDa protein was not susceptible to bacterial collagenase and thrombin, but was cleaved by cyanogen bromide. The protein was stained blue with Stains-all. Among various lectins, concanavalin A and lentil lectin agglutinin bound to this protein, but peanut agglutinin, Ricinus communis agglutinin, phytohemagglutinin-E and wheatgerm lectin agglutinin did not. Lectin binding assays showed that the protein is a glycoprotein containing large amounts of mannose and/or glucose residues, but is not a fragment of proteoglycan. The amino acid composition of the protein shows a characteristically high content of acidic amino acids. Therefore, the mineral-binding $40-\mathrm{kDa}$ glycoprotein is considered to be osteonectin/secreted protein acidic and rich in cysteine (SPARC), in terms of similarities to bovine and porcine osteonectins with regard to molecular weight and contents of glycoses and amino acids.
\end{abstract}

\section{Introduction}

Several bone proteins have been isolated from mineralized matrix of bone, and their characteristics, especially those related to calcification and matrix formation, have been determined; small proteoglycans ${ }^{[1,2]}$, bone sialoprotein ${ }^{[3]}$, osteopontin $^{[4,5]}$, osteocalcin ${ }^{[6,7]}$, small collagenous proteins ${ }^{[8-10]}$ and osteonectin $^{[11-13]}$ have received special attention.

Among these, osteonectin was first characterized by Termine et al. ${ }^{[11]}$, who

前野正夫、田口稔、鈴木直人、大越哲也、長沼清、田村嘉之、中野喜右人、小森二三夫、大塚吉兵衛、 鈴木貫太郎

1 Department of Biochemistry, Nihon University School of Dentistry.

2 Department of Oral Surgery, Musashino Red Cross Hospital, 1-26-1 Kyonancho, Musashino-shi, Tokyo 180, JAPAN.

To whom all correspondence should be addressed: Dr. Masao MAENO, Department of Biochemistry, Nihon University School of Dentistry, 1-8-13 Kanda-Surugadai, Chiyoda-ku, Tokyo 101, JAPAN. 
demonstrated that it was a phosphorylated glycoprotein binding to both hydroxyapatite and collagen, and accounting for about $25 \%$ of all non-collagenous proteins in fetal bovine bone. With regard to the in vitro biosynthesis of osteonectin, OTsuKa et al. ${ }^{[14]}$ reported that osteonectin was produced by fetal porcine calvarial cells, and Kuwata et al. ${ }^{[15]}$ identified pre-osteonectin produced by cell-free translation of fetal porcine calvarial mRNA. Subsequently, DomenICUCCI et al. ${ }^{[12]}$ determined the amino acid sequence of osteonectin extracted from fetal porcine calvaria.

Recently, it was reported that osteonectin from adult bovine bone inhibited hydroxyapatite crystal formation more strongly than osteocalcin ${ }^{[16]}$, although it bound to a partially purified type I collagen preparation, as described by TERMINE et al. ${ }^{[11]}$.

Concerning osteonectin in alveolar bones, $\operatorname{EDA}^{[13]}$ reported that osteonectin extracted from rabbit mandibles was able to bind to both hydroxyapatite and gelatin, and determined its amino acid composition. However, its other properties are still unclear.

In this study, we purified a mineral-binding 40-kDa glycoprotein from alveolar bone of young adult rabbit and clarified its characteristics; the protein was treated with bacterial collagenase, thrombin and cyanogen bromide, and its lectin-binding abilities and amino acid composition were determined. The data obtained indicated that this $40-\mathrm{kDa}$ glycoprotein was rabbit alveolar bone osteonectin.

\section{Materials and Methods}

\section{Extraction Procedures}

Bone proteins of rabbit( 3 months old) mandibular alveolar bone were extracted according to the three-step procedure described by OHMORI et al. ${ }^{[17]}$. The alveolar bone blocks were carefully cleaned to avoid contamination with surrounding soft tissues, and frozen in liquid nitrogen. Then, the bone blocks were broken with a mortar and pestle into small pieces (less than $8 \mathrm{~mm}^{3}$ ).

Fifty grams of the fragmented bone was washed overnight with ice-cold phosphate-buffered saline solution (PBS), pH 7.4, deficient in $\mathrm{Ca}^{2+}$ and supplemented with the following protease inhibitors (PIs): $1 \mathrm{mM}$ phenylmethylsulfonyl fluoride, $5 \mathrm{mM}$ benzamidine hydrochloride, $10 \mathrm{mM} \varepsilon$-amino caproic acid and $5 \mathrm{mM}$ N-ethylmaleimide. First, the bone fragments were washed with 2 liters of $4 \mathrm{M}$ guanidine hydrochloride solution $(\mathrm{GuHCl})$ containing the PIs with constant stirring to remove organic materials bound to the non-mineralized phase of the fragments; the $\mathrm{pH}$ value of the solution was adjusted to 7.4 with $50 \mathrm{mM}$ Tris- $\mathrm{HCl}$ buffer. The fragments were rinsed for 5 days by changing the $\mathrm{GuHCl}$ solution every day, and the supernatant solution was collected by centrifugation for recovery of organic materials; this fraction was termed the $\mathrm{G}_{1}$-extract.

Subsequently, the bone fragments were rinsed with 2 liters of PBS-PI/day for 3 days, and then organic materials in the mineral phase of the bones were extracted with 2 liters of $0.5 \mathrm{M}$ ethylenediaminetetraacetic acid (EDTA) containing PIs for 10 days, changing the solution five times in 2 days; the $\mathrm{pH}$ was adjusted to 7.4 with 
Tris- $\mathrm{HCl}$ buffer. The supernatant fraction containing the proteins from the mineral phase was recovered by centrifugation; this fraction was termed the E-extract.

The demineralized collagenous residues of the bones were again rinsed with 2 liters of PBS-PI/day for 3 days, and the proteins were extracted with the above $\mathrm{GuHCl}$ solution in the same way. The supernatant containing the proteins in the matrix phase was recovered by centrifugation, and termed the $\mathrm{G}_{2}$-extract.

Each extract was concentrated 200-fold by ultrafiltration on a Diaflo membrane (PM-10, Amicon Corp., Lexington, MA, USA), and dialyzed exhaustively against $0.1 \mathrm{M}$ ammonium bicarbonate solution containing $0.005 \%(\mathrm{v} / \mathrm{v})$ Brij 35 (Sigma Chemical Co., St. Louis, MO, USA). Then, the solution of each extract was freeze-dried for use.

\section{SDS-Polyacrylamide Gel Electrophoresis}

SDS-Polyacrylamide gel electrophoresis (SDS-PAGE) was carried out using 5-20\% gradient cross-linked polyacrylamide gels with a discontinuous Tris/glycine buffer system as described by LAEMMLI ${ }^{[18]}$; minislab gradient gels $0.75 \mathrm{~mm}$ thick were made with a Mighty Small II (Hoefer Scientific Instruments, San Francisco, CA, USA). The freeze-dried preparations described above were dissolved in 10-15 $\mu 1$ of sample buffer for SDS-PAGE consisting of $1 \%$ SDS, 2 M urea and bromophenol blue marker, which was heated at $90^{\circ} \mathrm{C}$ for $5 \mathrm{~min}$ before application to the slab-gels. For SDS-PAGE under reducing conditions, $15 \mathrm{mg}$ of dithiothreitol was added to $1 \mathrm{ml}$ of the sample buffer before heating. The electrophoresis was carried out at a constant voltage of $150 \mathrm{~V}$ for $60 \mathrm{~min}$. After the electrophoresis, the gel was stained with $0.2 \%(\mathrm{w} / \mathrm{v})$ silver nitrate ${ }^{[19]}$ or $0.025 \%(\mathrm{w} / \mathrm{v})$ Stains-all ${ }^{[20]}$.

\section{Purification Procedures}

Approximately $200 \mathrm{mg}$ of the freeze-dried E-extract from $50 \mathrm{~g}$ of the bone blocks (wet weight) was dissolved in $2 \mathrm{ml}$ of $4 \mathrm{M} \mathrm{GuHCl}(\mathrm{pH} 7.4)$, and centrifuged at $10,000 \times \mathrm{g}$ for $30 \mathrm{~min}$. The supernatant fraction was applied to a Sepharose CL-6B column $(2.6 \times 90 \mathrm{~cm}$, Pharmacia Fine Chemicals, Uppsala, Sweden); elution was performed at a flow rate of $10 \mathrm{ml} / \mathrm{h}$, and 2- $\mathrm{ml}$ fractions were collected. The fractions containing proteins of 35 to $45 \mathrm{kDa}$ were separately pooled, desalted with a PD-10 column $(1.5 \times 5 \mathrm{~cm}$, Pharmacia Fine Chemicals) and freeze-dried for the next step.

The freeze-dried material was dissolved with $10 \mathrm{mM}$ Tris- $\mathrm{HCl}$ buffer containing $7 \mathrm{M}$ urea $(\mathrm{pH} 7.4)$, and applied to an analytical column $(0.78 \times 7.5 \mathrm{~cm}$, Shinwa Kako Co., Kyoto, Japan) filled with DEAE-Sepharose resin (Pharmacia Fine Chemicals). The proteins were eluted with a linear gradient of $\mathrm{NaCl}(0$ to $1.0 \mathrm{M})$ at a flow rate of $1.0 \mathrm{ml} / \mathrm{min}$ using a high-pressure liquid chromatography (HPLC) system (Shimadzu Corp., Kyoto, Japan), and 1.0-ml fractions were collected. The fractions containing the $40-\mathrm{kDa}$ protein were pooled, desalted using a PD-10 column and freeze-dried for the following step.

The freeze-dried material was dissolved in $500 \mu \mathrm{l}$ of $10 \mathrm{mM}$ Tris-HCl buffer

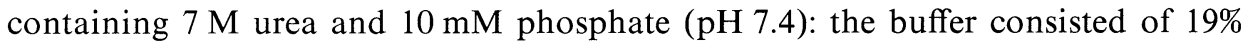
$\mathrm{NaH}_{2} \mathrm{PO}_{4}$ and $81 \% \mathrm{Na}_{2} \mathrm{HPO}_{4}$. The sample solution was applied to an analytical hydroxyapatite column $(0.75 \times 5 \mathrm{~cm}$, Tonen Corp., Tokyo, Japan $)$ equilibrated with the above buffer. After applying the sample solution at a flow rate of $0.2 \mathrm{ml} /$ 
min, the column was washed with $19 \mathrm{ml}$ of the buffer at a flow rate of $0.5 \mathrm{ml} / \mathrm{min}$, and the proteins were eluted with a linear gradient of 10 to $500 \mathrm{mM}$ phosphate at a flow rate of $0.5 \mathrm{ml} / \mathrm{min}$ using a HPLC system; $1.0-\mathrm{ml}$ fractions were collected. The fractions containing the $40-\mathrm{kD}$ a protein were pooled, desalted with a PD-10 column and freeze-dried for final purification.

The freeze-dried material containing the $40-\mathrm{kDa}$ protein was dissolved in 500 $\mu 1$ of $50 \mathrm{mM}$ Tris- $\mathrm{HCl}, \mathrm{pH} 7.4$, and applied to an analytical column $(0.5 \times 5 \mathrm{~cm}$, Pharmacia Fine Chemicals) of Mono Q resin. The protein was eluted with a linear gradient of 0 to $1.0 \mathrm{M} \mathrm{NaCl}$ at a flow rate of $1.0 \mathrm{ml} / \mathrm{min}$ using the HPLC system, and $1.0-\mathrm{ml}$ fractions were collected. The purity of the protein preparation was assessed by staining slab-gels with silver or Stains-all to visualize the protein bands. The fractions containing the proteins of interest were desalted using the PD-10 column to determine some of their characteristics.

Digestion with Bacterial Collagenase

The purified $40-\mathrm{kDa}$ protein was incubated with highly purified bacterial collagenase (22.5 unit/0.084 mg, Advance Biofactures Co., Linbrook, NY, USA); the enzyme was used at one tenth of the protein concentration. The digestion was performed at $37^{\circ} \mathrm{C}$ for $60 \mathrm{~min}$ in $20 \mu \mathrm{l}$ of $50 \mathrm{mM}$ Tris- $\mathrm{HCl}, \mathrm{pH} 7.4$, supplemented with $5 \mathrm{mM} \mathrm{CaCl}_{2}$ and $5 \mathrm{mM}$ N-ethylmaleimide.

Digestion with Thrombin

The purified protein was treated with thrombin (100 unit/0.05 mg, Sigma Chemical Co.), using the same enzyme-protein concentration described above. The digestion was performed at $37^{\circ} \mathrm{C}$ for $60 \mathrm{~min}$ in $20 \mu \mathrm{l}$ of $10 \mathrm{mM}$ Tris- $\mathrm{HCl}$ buffer, $\mathrm{pH}$ 8.0, supplemented with $10 \mathrm{mM} \mathrm{CaCl}$.

\section{Cleavage with Cyanogen Bromide}

The purified protein was dissolved in $100 \mu \mathrm{l}$ of $70 \%(\mathrm{v} / \mathrm{v})$ formic acid, and flushed with nitrogen for $1 \mathrm{~min}$. Approximately $1 \mathrm{mg}$ of cyanogen bromide crystals was added to $5 \mu \mathrm{g}$ of the protein. The contents were briefly flushed again with nitrogen before sealing the tube, and incubated at $27^{\circ} \mathrm{C}$ for $4 \mathrm{~h}$. The solution was then diluted 40-fold with water, and freeze-dried. The sample was dissolved in water and again freeze-dried to remove residual cyanogen bromide.

\section{Western Blotting}

The binding abilities of several HRP-conjugated lectins to $500 \mathrm{ng}$ of the 40-kDa protein were determined using the following lectins: concanavalin A (Con A), lentil lectin agglutinin (LCA), peanut agglutinin (PNA), Ricinus communis agglutinin (RCA), phytohemagglutinin-E (PHA) and wheatgerm lectin agglutinin (WGA).

Immunotransfer analysis was performed on a Multiphor II Novo Blot system (LKB, Uppsala, Sweden) using a nitrocellulose membrane (Bio-Rad Laboratories, Richmond, CA, USA) with a continuous buffer system composed of $39 \mathrm{mM}$ glycine, $48 \mathrm{mM}$ Tris, $0.0375 \%$ SDS and $20 \%$ (v/v) methanol. Electrophoresis was carried out at a constant current of $0.8 \mathrm{~mA} / \mathrm{cm}^{2}$ of gel for 60 to $90 \mathrm{~min}$. After the transfer, the excess protein-binding sites on the membrane were blocked with $3 \%$ bovine serum albumin (BSA; Inter Gen, Kankakee, IL, USA) dissolved in $10 \mathrm{mM}$ Tris-buffered saline containing $145 \mathrm{mM} \mathrm{NaCl}, \mathrm{pH} 7.4$, (TBS), at $4^{\circ} \mathrm{C}$ for $18 \mathrm{~h}$. The 
membrane was then washed three times with TBS containing $0.05 \%$ Tween-20 (TBS-Tween). The sheets were incubated at $22^{\circ} \mathrm{C}$ for $60 \mathrm{~min}$ with each HRPconjugated lectin diluted 1:200 with TBS containing 3\% BSA. The sheets were washed three times with TBS-Tween, and once with TBS. The membrane was then incubated with TBS containing 0.06\% 4-chloro-1-naphthol, and 0.04\% $\mathrm{H}_{2} \mathrm{O}_{2}$.

Amino Acid Analysis

The purified 40-kDa protein was hydrolyzed with $6.0 \mathrm{~N} \mathrm{HCl}$ at $110^{\circ} \mathrm{C}$ for 22 $\mathrm{h}$ in a nitrogen-flushed tube. The amino acid composition of the protein was determined using a Shimadzu amino acid analyzer (column: Shim-pak ISC-07/ S1504 Na, Shimadzu Corp.).

\section{Results}

Proteins present in rabbit alveolar bone were sequentially extracted, initially with $4 \mathrm{M} \mathrm{GuHCl}$, then with $0.5 \mathrm{M}$ EDTA, followed by $4 \mathrm{M} \mathrm{GuHCl}$ solution; the extracts obtained were termed $\mathrm{G}_{1}$-extract, E-extract and $\mathrm{G}_{2}$-extract, respectively. The proteins in each extract were then analyzed by SDS-PAGE using Stains-all (Fig. 1). Among the three extracts, the E-extract contained a limited number of clearly resolved proteins migrating at positions corresponding to molecular masses of $80 \sim 67 \mathrm{kDa}$ and $55 \sim 40 \mathrm{kDa}$, with some faint bands below the $40-\mathrm{kDa}$ region. A predominant protein (arrowhead in Fig. 1) in the E-extract was purified by column chromatography using an automated HPLC system.

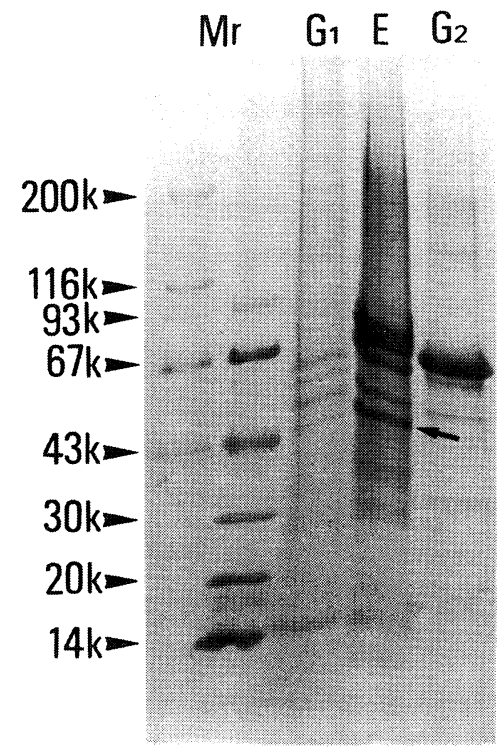

Fig. 1 SDS-PAGE analysis of proteins extracted from alveolar bone of young adult rabbit SDS-PAGE (5-20\% gradient cross-linked gel) was performed under reducing conditions to separate the proteins, which were then stained with Stains-all. $\mathrm{Mr}$ values indicate molecular weight marker proteins. G1, proteins extracted with $4 \mathrm{M} \mathrm{GuHCl}$ (G1-extract); E, proteins extracted with $0.5 \mathrm{M}$ EDTA (E-extract); G2, proteins extracted with $4 \mathrm{M} \mathrm{GuHCl}$ a second time (G2-extract). 
Proteins in the E-extract were first fractionated by gel filtration on Sepharose $\mathrm{CL}-6 \mathrm{~B}$ in the presence of $4 \mathrm{M} \mathrm{GuHCl}$. An elution profile of the CL-6B run is shown in Fig. 2. Proteins in every third fraction of the run were monitored by SDS-PAGE under reducing conditions, and the fractions containing $45 \sim 35-\mathrm{kDa}$ proteins were pooled (bar in Fig. 2). The pooled material was then applied to a DEAE-Sepharose column, and eluted using a linear gradient of $\mathrm{NaCl}(0 \sim 1.0 \mathrm{M})$

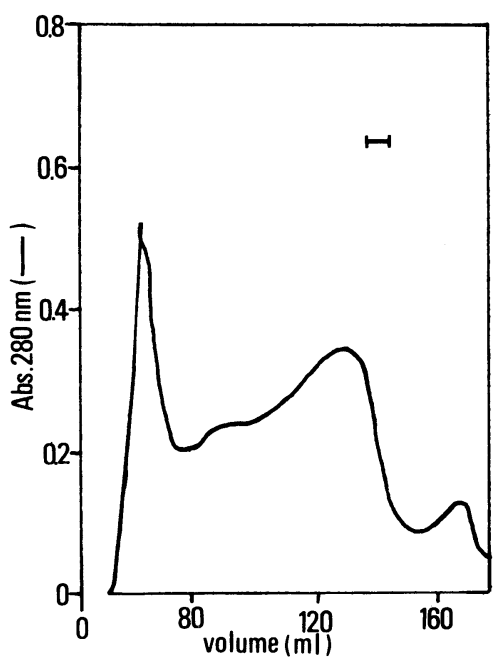

Fig. 2 Sepharose CL-6B column chromatography of E-extract

Approximately $50 \mathrm{mg}$ of the E-extract was dissolved in $2.0 \mathrm{ml}$ of $4 \mathrm{M} \mathrm{GuHCl}$ in $50 \mathrm{mM}$ Tris- $\mathrm{HCl}, \mathrm{pH} 7.4$, and the solution clarified by centrifugation. The solution was applied to a Sepharose CL-6B column $(2.6 \times 90 \mathrm{~cm})$, which was eluted at $10 \mathrm{ml} / \mathrm{h}$, and $2.0-\mathrm{ml}$ fractions were collected. Protein concentrations in the eluate were monitored by absorbance at $280 \mathrm{~nm}$. Fractions containing $35 \sim 45-\mathrm{kDa}$ proteins were pooled (bar), desalted on PD-10, and then freeze-dried.

in $7 \mathrm{M}$ urea. The proteins were separated into three symmetrical peaks as illustrated in Fig. 3, except for the flowthrough fraction. According to the gel staining after SDS-PAGE, a 40-kDa protein showed the highest peak eluting with $250 \mathrm{mM}$ $\mathrm{NaCl}$, and the fractions containing this protein were pooled (bar in Fig. 3). The pooled material was suspended in $10 \mathrm{mM}$ phosphate with $7 \mathrm{M}$ urea, and applied to a hydroxyapatite column. The protein was separated into two peaks, a small unbound peak and a large peak bound to the hydroxyapatite, as shown in Fig. 4; the $40-\mathrm{kDa}$ protein was in the bound peak (bar in Fig. 4). After combining the fractions containing the bound peak, the pooled material was applied to a Mono $\mathrm{Q}$ column in the presence of $7 \mathrm{M}$ urea, and each fraction was determined by SDS-PAGE. The 40-kDa protein was purified to apparent homogeneity with a sharp symmetrical peak (bar in Fig. 5).

The purified 40-kDa protein was stained strongly with silver (Fig. 6, lane 1), and also stained blue with Stains-all (Fig. 6, lane 8) after SDS-PAGE under reducing conditions. Under non-reducing conditions, however, the protein band was stained weakly with silver; the band migrated to the same position as that 


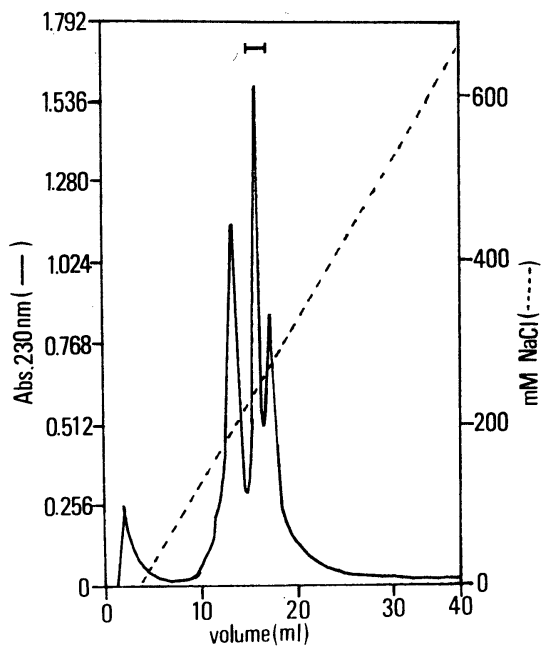

Fig. 3 DEAE-Sepharose column chromatography

The freeze-dried material pooled from the CL-6B run was dissolved in $500 \mu \mathrm{l}$ of $50 \mathrm{mM}$ Tris- $\mathrm{HCl}, \mathrm{pH} 7.4$, containing $7 \mathrm{M}$ urea and applied to a DEAE-Sepharose column $(0.78 \times 7.5$ $\mathrm{cm})$. The proteins were eluted with a linear gradient of $\mathrm{NaCl}(0-1.0 \mathrm{M})$, and the eluate was collected in $1.0-\mathrm{ml}$ fractions; the column was run at $1.0 \mathrm{ml} / \mathrm{min}$. Protein concentrations in the eluate were monitored by absorbance at $230 \mathrm{~nm}$. Fractions containing the $40-\mathrm{kDa}$ protein were pooled (bar), desalted on PD-10, and then freeze-dried.

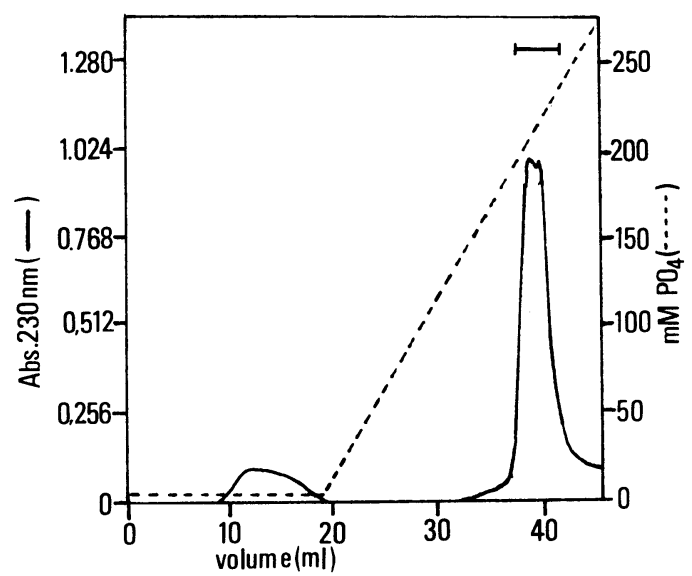

Fig. 4 Hydroxyapatite column chromatography

The freeze-dried material pooled from the DEAE column was dissolved in $500 \mu 1$ of a starting buffer ( $50 \mathrm{mM}$ Tris- $\mathrm{HCl}, \mathrm{pH} 7.4$, containing $10 \mathrm{mM}$ phosphate and $7 \mathrm{M}$ urea), and applied to a hydroxyapatite column $(0.75 \times 5 \mathrm{~cm})$ at $0.2 \mathrm{ml} / \mathrm{min}$. The column was washed with the starting buffer at $0.5 \mathrm{ml} / \mathrm{min}$, and the proteins were eluted with a linear gradient of $10-500 \mathrm{mM} \mathrm{PO}_{4}$ at the same flow rate, $1.0-\mathrm{ml}$ fractions being collected. Protein concentrations were monitored by absorbance at $230 \mathrm{~nm}$. Fractions containing the $40-\mathrm{kDa}$ protein were pooled (bar), desalted on PD-10, and then freeze-dried. 


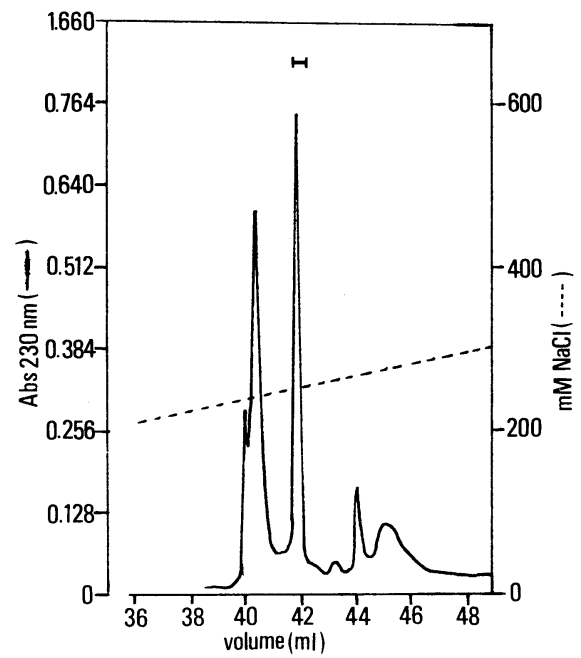

Fig. 5 Mono Q column chromatography

The freeze-dried material pooled from the hydroxyapatite column was dissolved in $500 \mu \mathrm{l}$ of 50 $\mathrm{mM}$ Tris- $\mathrm{HCl}, \mathrm{pH} 7.4$, containing $7 \mathrm{M}$ urea and applied to a Mono Q column $(0.5 \times 5.5 \mathrm{~cm})$. Proteins were eluted with a linear gradient of $\mathrm{NaCl}(0-1.0 \mathrm{M})$ and $1.0-\mathrm{ml}$ fractions were collected; the column was run at $1.0 \mathrm{ml} / \mathrm{min}$. Protein concentrations were monitored by absorbance at $230 \mathrm{~nm}$. Fractions containing the $40-\mathrm{kDa}$ protein were pooled (bar), desalted on PD-10, and then freeze-dried to determine some of the characteristics of the 40-kDa protein.

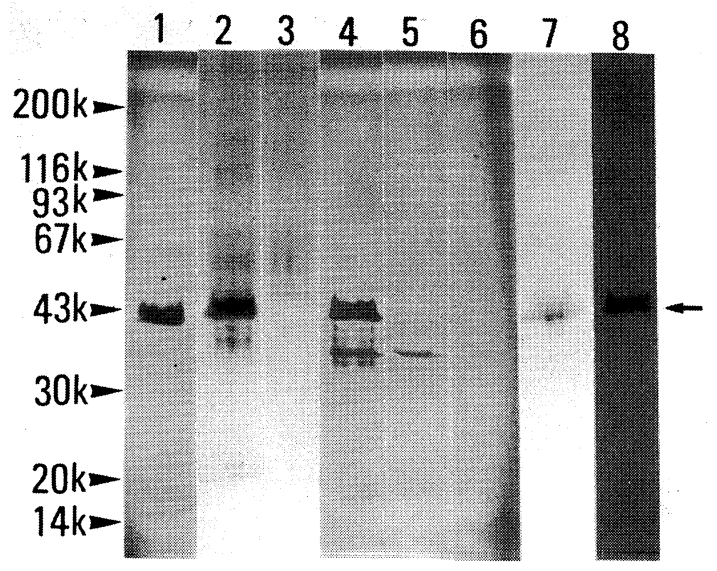

Fig. 6 Characterization of the purified 40-kDa protein

The purified $40-\mathrm{kDa}$ protein was applied to a gradient gel (5-20\%) on a minislab system under reducing (lanes 1-6 and 8) or non-reducing (lane 7) conditions. The SDS-polyacrylamide gel was stained with silver (lanes 1-7) or Stains-all (lane 8). Lane 1, the 40-kDa protein stained with silver under reducing conditions; Lane 2, the protein treated with bacterial collagenase; Lane 3, bacterial collagenase; Lane 4, the protein treated $w$ ith thrombin; Lane 5 , thrombin; Lane 6 , the protein cleaved with cyanogen bromide; Lane 7, the protein stained with silver under nonreducing conditions; Lane 8 , the protein stained blue with Stains-all. 
under reducing conditions.

The 40-kDa protein was incubated with bacterial collagenase or thrombin at $37^{\circ} \mathrm{C}$ for $60 \mathrm{~min}$, but was not susceptible to these enzymes (Fig. 6, lanes 2 and 4).

Upon incubation with cyanogen bromide at $27^{\circ} \mathrm{C}$ for $4 \mathrm{~h}$, the protein was completely cleaved (Fig. 6, lane 6).

Lectin-binding assays carried out by Western blotting showed that Con A and LCA bound to this protein, whereas PNA, RCA, PHA and WGA did not (Fig. 7).

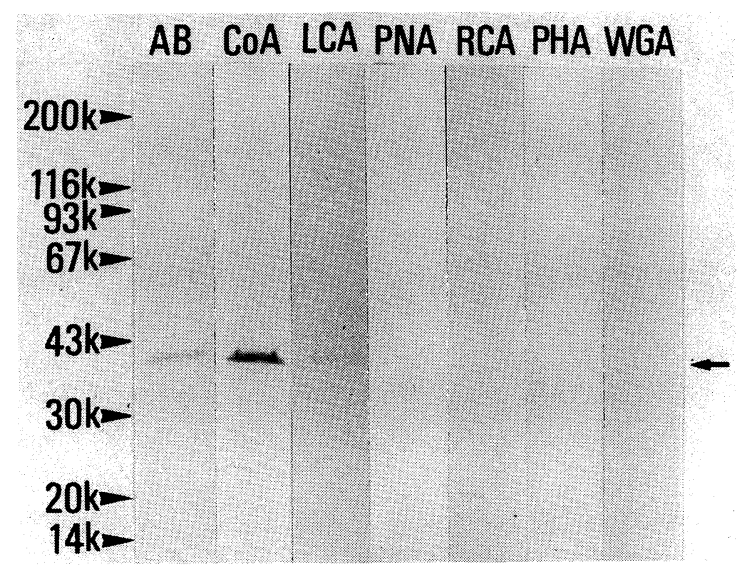

Fig. 7 Western blotting using several HRP-conjugated lectins

The $40-\mathrm{kDa}$ protein was transferred to nitrocellulose membrane, and incubated with various HRP-conjugated lectins. AB, the 40-kDa protein stained with amido black; CoA, concanavalin A; LCA, lentil lectin agglutinin; PNA, peanut agglutinin; RCA, Ricinus communis agglutinin; PHA, phytohemagglutinin; WGA, wheatgerm lectin agglutinin.

Table 1 Amino acid composition of 40-kDa protein

\begin{tabular}{|c|c|c|c|c|}
\hline \multirow[b]{2}{*}{ Amino acid } & \multicolumn{4}{|c|}{ Composition (residues/1000 residues) } \\
\hline & $\begin{array}{l}\text { Young adult-rabbit } \\
\text { alveolar bone } \\
\text { 40-kDa glycoprotein }\end{array}$ & $\begin{array}{l}\text { Fetal-porcine } \\
\text { calvaria } \\
\text { osteonectin* }\end{array}$ & $\begin{array}{l}\text { Fetal-bovine } \\
\text { long bone } \\
\text { osteonectin** }\end{array}$ & $\begin{array}{l}\text { Murine } \\
\text { endoderm } \\
\text { SPARC protein } * * *\end{array}$ \\
\hline Hydroxyproline & 0 & 0 & 0 & - \\
\hline Aspartate & 126 & 124 & 130 & 116 \\
\hline Threonine & 52 & 49 & 59 & 60 \\
\hline Serine & 35 & 26 & 42 & 25 \\
\hline Glutamate & 189 & 179 & 148 & 158 \\
\hline Proline & 69 & 66 & 72 & 25 \\
\hline Glycine & 63 & 52 & 65 & 56 \\
\hline Alanine & 54 & 53 & 58 & 49 \\
\hline Cystine & 11 & 35 & 6 & 49 \\
\hline Valine & 76 & 65 & 69 & 70 \\
\hline Methionine & 5 & 11 & 11 & 18 \\
\hline Isoleucine & 34 & 38 & 37 & 42 \\
\hline Leucine & 91 & 93 & 90 & 84 \\
\hline Tyrosine & 12 & 26 & 24 & 24 \\
\hline Phenylalanine & 45 & 44 & 44 & 42 \\
\hline Histidine & 41 & 54 & 44 & 42 \\
\hline Lysine & 64 & 64 & 71 & 67 \\
\hline Arginine & 31 & 31 & 28 & 28 \\
\hline Tryptophan & 0 & 10 & ND & 10 \\
\hline
\end{tabular}


The amino acid composition of this protein is shown in Table 1. The protein possessed a high content of acidic amino acids or their amines (32\%), with leucine (9\%) and valine (8\%), but contained little methionine, cysteine and tyrosine; hydroxyproline and tryptophan were not detected.

\section{Discussion}

A sequential procedure for extraction of bone proteins, employing $4 \mathrm{M}$ $\mathrm{GuHCl}$ followed by $4 \mathrm{M} \mathrm{GuHCl}$ with $0.5 \mathrm{M}$ EDTA, has frequently been used to isolate mineral-binding proteins ${ }^{[1,3,6,11]}$. However, as this method extracts all of the materials present in both the mineral and matrix phases, the present study utilized a three-step extraction procedure to characterize mineral-binding proteins in the second extract, as described by Domenicucci etal. ${ }^{[12]}$. This involved GuHCl $\left(\mathrm{G}_{1}\right.$-extract), followed by EDTA without $\mathrm{GuHCl}$ (E-extract), and then $\mathrm{GuHCl}$ $\left(\mathrm{G}_{2}\right.$-extract).

Rabbit alveolar bone proteins were sequentially extracted using this method, and analyzed by SDS-PAGE with staining of the protein bands using silver or Stains-all. The E-extract contained some distinct proteins, giving major bands at $80 \sim 67 \mathrm{kDa}, 55 \sim 40 \mathrm{kDa}$ and $14.4 \mathrm{kDa}$, which were strongly stained blue with Stains-all. We focused on a mineral-binding $40-\mathrm{kDa}$ protein positive with Stainsall, and purified it using four kinds of column.

Proteins in the E-extract were first fractionated by Sepharose CL-6B column chromatography in the presence of $4 \mathrm{M} \mathrm{GuHCl}$. The eluate containing $45 \sim 35-\mathrm{kDa}$ proteins was pooled to purify the mineral-binding $40-\mathrm{kDa}$ protein by HPLC; the columns utilized were DEAE-Sepharose, hydroxyapatite and Mono Q columns in the presence of $7 \mathrm{M}$ urea.

$\mathrm{EDA}^{[13]}$ had shown previously that osteonectin in rabbit alveolar bone was eluted with $61 \mathrm{mM}$ phosphate on hydroxyapatite (Bio-Rad Laboratories, Richmond, CA, USA) column chromatography. However, we found that the mineralbinding $40-\mathrm{kDa}$ protein was eluted with $210 \mathrm{mM}$ phosphate on a hydroxyapatite column (Tonen Corp.). This difference may have been due to the type of hydroxyapatite packed in the column.

The mineral-binding 40-kDa protein was purified to apparent homogeneity in the sharp symmetrical peak on final purification by Mono Q column chromatography. The protein was strongly stained with silver upon gel-staining after SDSPAGE under reducing conditions. Under non-reducing conditions, however, the protein staining was weak in comparison with that under reducing conditions. These results suggested that the protein was a glycoprotein. Also, like bovine ${ }^{[11]}$ and porcine ${ }^{[12]}$ osteonectins, the protein was stained blue with Stains-all, suggesting that it was rich in acidic groups and/or phosphate.

Since MAENo et al. ${ }^{[10]}$ showed previously that a $28-\mathrm{kDa}$ protein in the E-extract of rabbit alveolar bone was digested by bacterial collagenase, producing a $19-\mathrm{kDa}$ fragment, and NAGATA et al. ${ }^{[5]}$ showed that a $44-\mathrm{kDa}$ osteopontin synthesized by rat bone cells was digested with thrombin, producing a $26 \sim 28-\mathrm{kDa}$ fragment, the $40-\mathrm{kDa}$ glycoprotein was incubated with bacterial collagenase or thrombin, and the molecular weight of the product was determined by SDS- 
PAGE. It was found that the protein was not susceptible to either enzyme, indicating that it was neither a collagenous protein nor osteopontin.

TERmine et al. ${ }^{[1]}$ showed that calf osteonectin contains sialic acid, glucosamine and galactosamine as carbohydrate side chains. Therefore, to determine the type of carbohydrate in the $40-\mathrm{kDa}$ glycoprotein, the binding of lectins was analyzed by Western blotting. Con A and LCA bound to the protein, but PNA, RCA, PHA and WGA did not. These results suggest that the protein has mannose and/or glucose residues as carbohydrate chains, and that it is not a proteoglycan fragment. Furthermore, the protein was cleaved completely with cyanogen bromide, suggesting that it contains methionine residues.

The amino acid composition of the protein showed a characteristically high content of acidic amino acids and/or their amines, together with leucine, proline, lysine and glycine residues similar to the composition of calf ${ }^{[11]}$ and porcine ${ }^{[12]}$ osteonectin and murine SPARC protein ${ }^{[21]}$.

These results suggest that the present mineral-binding $40-\mathrm{kDa}$ glycoprotein extracted from alveolar bone of young adult rabbit is the same protein as osteonectin/SPARC proteins from other tissues.

\section{Acknowledgements}

We thank Miss Hiromi YANO (student of Nihon University School of Dentistry) for her helpful assistance.

This study was supported by the Satoh Foundation of Nihon University School of Dentistry.

\section{References}

[1] Fisher, L. W., Termine, J. D., Dejter, S. W. Jr., Whitson, S. W., Yanagishita, M., Kimura, J. H., Hascall, V. C., Kleinman, H. K., Hassel, J. R. and Nilsson, B.: Proteoglycans of developing bone, J. Biol. Chem., 258, 6588-6594, 1983

[2] Takagi, M., Maeno, M., Kagami, A., Takahashi, Y. and Otsuka, K.: Biochemical and immunocytochemical characterization of mineral-binding proteoglycans in rat bone, $J$. Histochem. Cytochem., 39, 41-50, 1991

[3] Fisher, L. W., Whitson, S. W., Avioli, L. V. and Termine, J. D.: Matrix sialoprotein of developing bone, J. Biol. Chem., 258, 12723-12727, 1983

[4] Prince, C. W., Oosawa, T., Butler, W. T., Tomana, M., Bhown, A. S., Bhown, M. and SCHrohenloher, R. E.: Isolation, characterization, and biosynthesis of a phosphorylated glycoprotein from rat bone, J. Biol. Chem., 262, 2900-2907, 1987

[5] Nagata, T., Todescan, R., Goldberg, H. A., Zhang, Q. and Sodek, J.: Sulphation of secreted phosphoprotein I (SPPI, osteopontin) is associated with mineralized tissue formation, Biochem. Biophys. Res. Commun., 165, 234-240, 1989

[6] Price, P. A., Otsuka, A. S., Poser, J. W., Kristanponis, J. A. and Raman, N.: Characterization of a $\gamma$-carboxyglutamic acid-containing protein from bone, Proc. Natl. Acad. Sci. USA, 73, 1447-1451, 1976

[7] Price, P. A. and Williamson, M. K.: Primary structure of bovine matrix Gla protein, a new vitamin K-dependent bone protein, J. Biol. Chem., 260, 14971-14975, 1985

[8] Goldberg, H. A., Maeno, M., Domenicucci, C., Zhang, Q., and Sodek, J.: Identification of small collagenous proteins with properties of procollagen $\alpha 1$ ( I ) pN-propeptide in fetal porcine calvarial bone, Collagen Rel. Res., 8, 187-197, 1988

[9] Sodek, J., Goldberg, H. A., Domenicucci, C., Zhang, Q., Kwon, B., Maeno, M. and Kuwata, F.: Characterization of multiple forms of small collagenous apatite-binding 
proteins in bone, Connective Tissue Res., 20, 233-240, 1989

[10] Maeno, M., Suzuki, N., Ohmori, Y., Saito, R., Shioji, S., Sato, K., Otsuka, K. and SuzuKI, K.: Characterization of a $28-\mathrm{kDa}$ collagenous protein extracted with EDTA from adult rabbit alveolar bone, $J B M M, \mathbf{1 0}$, in press

[11] Termine, J. D., Belcourt, A. B., Conn, K. M. and Kleinman, H. K.: Mineral and collagenbinding proteins of fetal calf bone, J. Biol. Chem., 256, 10403-10408, 1981

[12] Domenicucci, C., Goldberg, H. A., Isenman, D., Hofmann, T., Wasi, S. and Sodek, J.: Characterization of porcine osteonectin extracted from foetal calvariae, Biochem. J., 253, 139-151, 1988

[13] EDA, H.: Isolation and characterization of osteonectin from rabbit alveolar bone, Kanagawa Shigaku, 21, 555-566, 1987 (in Japanese)

[14] Otsuka, K., Yao, K-L., Wasi, S., Tung, P. S., Aubin, J. E., Sodek, J. and Termine, J. D.: Biosynthesis of osteonectin by fetal porcine calvarial cells in vitro, J. Biol. Chem., 259, 9805-9812, 1984

[15] Kuwata, F., Yao, K-L., Sodek, J., Ives, S. and Pulleyblank, D.: Identification of preosteonectin produced by cell-free translation of fetal porcine calvarial mRNA, J. Biol. Chem., 260, 6993-6998, 1985

[16] Romberg, R. W., Werness, P. G., Riggs, B. L. and Mann, K. G.: Inhibition of hydroxyapatite crystal growth by bone-specific and other calcium-binding proteins, Biochemistry, 25, 1176-1180, 1986

[17] Ohmori, Y., Suzuki, N., Maeno, M., Endo, T., Yajima, M., Inoue, T., Yamaguchi, T. and OTsuкA, K.: Comparison of protein profiles on SDS-PAGE between EDTA and guanidine$\mathrm{HCl}$ extracts from rabbit alveolar bone, Nihon Univ. Dent. J., 63, 86-92, 1989 (in Japanese)

[18] Laemmli, U. K.: Cleavage of structural proteins during the assembly of the head of bacteriophage T4, Nature, 227, 680-685, 1970

[19] Merril, C. R., Goldman, D. and Keuren, M. L.: Simplified silver protein detection and image enhancement methods in polyacrylamide gel, Electrophoresis, 3, 17-23, 1982

[20] Campbell, K. P., Maclennan, D. H. and Jorgensen, A. O.: Staining of the $\mathrm{Ca}^{2+}$-binding proteins, calsequestrin, calmodulin, troponin C, and S-100, with the cationic carbocyanine dye "Stains-all", J. Biol. Chem., 258, 11267-11273, 1983

[21] Mason, I. J., Taylor, A., Williams, J. G., Sage, H. and Hogan, B. L. M.: Evidence from molecular cloning that SPRC, a major product of mouse embryo parietal endoderm, is related to an endothelial cell 'culture shock' glycoprotein of $\mathrm{Mr} 43,000, E M B O \mathrm{~J} ., 5$, $1465-1472,1986$ 